\title{
Upaya Meningkatkan Aktivitas Dan Hasil Belajar Bahasa Inggris Peserta didik Kelas VII-4 Semester Satu Tahun Pelajaran 2019/2020 dengan Menerapkan Model Lightening The Learning Climate (Menghidupkan suasana belajar) di SMP Negeri 4 Mataram
}

\author{
Dewi Saprilan \\ Guru Bahasa Inggris SMP Negeri 4 Mataram
}

\begin{abstract}
Abstrak
Penelitian ini bertujuan untuk mengetahui efektifitas penerapan model Lightening The Learning Climate (Menghidupkan suasana belajar) dalam upaya meningkatkan Aktifitas dan hasil belajar Bahasa Inggris Peserta didik kelas VII-4 SMP Negeri 4 Mataram. Manfaat penelitian ini adalah sebagai bahan kajian dan bahan temuan dalam pelaksanaan proses pembelajaran di kelas senyatanya. Bagi guru untuk meningkatkan kompetensi dalam proses pembelajaran dan bagi peserta didik untuk meningktakan Aktifitas belajar yang berdampak meningkatnya hasil belajar peserta didik. Penelitian ini dilaksanakan dua siklus, masing-masing siklus kegiatannya adalah; perencanaan, pelaksanaan, observasi dan refleksi. Hasil akhir tindakan pada siklus II pertemuan II menunjukkan bahwa hasil observasi guru memperoleh skor rata-rata $(4,36)$ dan hasil observasi peserta didik mencapai skor rata-rata $(4,53)$. Sedangkan dampak dari peningkatan Aktifitas belajar adalah meningkatnya perolehan hasil belajar peserta didik mencapai nilai rata-rata (80,52), artinya indikator keberhasilan $(\geq 4,0)$ telah terlampaui. Karena indicator keberhasilan telah terbukti penelitian dinyatakan berhasil dan dihentikan pada siklus II.
\end{abstract}

Kata Kunci : Aktifitas dan hasil Belajar - model Lightening The Learning Climate (Menghidupkan suasana belajar)

\section{PENDAHULUAN}

\section{Latar Belakang}

Proses pembelajaran khususnya pada mata pelajaran Bahassa Inggris pada umumnya sangat berbeda dengan mata pelajaran yang lain. Pada kelas pemula yang dalam hal ini kelas VII (tujuh), peserta didik masih banyak belum mengenal grammer, sehingga cara pendekatan dan strategi pembelajaran guru harus mampu menumbuhkan aktivitas peserta didik dalam proses pembelajaran di kelass senyatanya dengan cara interaksi komunikatif dengan semua peserta didik baik secara klasikal maupun individual. Pendekatan secara klasikal dibutuhkan sosok guru yang kreatif, inovatif, serta mampu membangkitkan minat belajar peserta didik, sementara pendekatan secara individual guru harus mampu beradaptassi dengan suasana kebatinan masing-masing peserta didik sesuai dengan karakteristik masing-masing.

Secara umum proses pembelajaran di SMP Negeri 4 Mataram sudah menerapkan kurikulum 2013 (K.13) dengan model pembelajaran yang fariatif sesuai dengan karakteristik mata pelajaran masing-masing. Khususnya untuk pembelajaran pada mata pelajaran Bahasa Inggris terlebih khusus lagi peserta didik kelas VII sudah menggunakan/menerapkan model pembelajaran yang actual seperti model Lightening The Learning Climate (Menghidupkan suasana belajar), active debat (debat aktif), point counterpoint (debat pendapat) akan tetapi belum optimal. Alasannya yakni masih dalam penyesuaian pola pembelajaran di sekolah dasar (SD)/madrasah Ibtidaiyah (MI) dengan model 
Jurnal Ilmu Sosial dan Pendidikan

http://ejournal.mandalanursa.org/index.php/JISIP/index

Terakreditasi Peringkat 5 (No. SK: 85/M/KPT/2020)

pembelajaran di SMP khususnya di SMP Negeri

4 Mataram.

Rendahnya aktivitas dan hasil belajar

Bahasa Inggris peserta didik kelass VII-4 pada semester satu tahun pelajaran 2019/2020 faktor penyebabnya adalah: 1) guru belum optimal dalam melaksanakan model pembelajaran "Lightening The Learning Climate (Menghidupkan suasana belajar)" pada mata pelajaran Bahasa Inggris peserta didik kelas VII4 semester satu tahun pelajaran 2019/2020,2) peserta didik ketika melaksanakan diskusi kelompok terkesan hanya beberapa anggota kelompok saja yang proaktif terhadap permasalahan yang hendak dipecahkan melalui diskusi kelompok, 3) dalam membuat laporan hasil kerja kelompok secara individu masih jauh dari harapan, begitu pula ketika peserta didik mengerjakan soal dalam bentuk tes tertulis terkesan kurang bersemangat dan acuh tak acuh apabila tidak bisa mengerjakan.

Sebenarnya ada beberapa solusi yang bisa dilakukan oleh guru mata pelajaran Bahassa Inggris selaku peneliti, diantaranya yaitu dengan mengoptimalkan penerapan model "Lightening The Learning Climate (Menghidupkan suasana belajar)". Alasannya karena model pembelajaran ini mempunyai beberapa keunggulan antara lain:

1) model pembelajaran "Lightening The Learning Climate (Menghidupkan suasana belajar)" sangat menyenangkan dan terkesan serius, santai, sukses $(3 \mathrm{~S}), 2$ ) peserta didik bisa memecahkan permasalahan pembelajaran melalui diskusi kelompok dan tukar pikiran dengan kelompok lain dalam kegiatan presentasi perkelompok di depan kelas, dan 3) terjalinnya nilai kekeluargaan, kebersamaan dan semangat kebatinan antara peserta didik dengan gur mata pelajaran Bahasa Inggris.

Untuk membuktikan beberapa keunggulan model "Lightening The Learning Climate (Menghidupkan suasana belajar)" dalam upaya meningkatkan aktivitas dan hasil belajar Bahasa Inggris peserta didik kelas VII-4 semester satu tahun pelajaran 2019/2020 di SMP Negeri 4 Mataram maka perlu diadakan Penelitian Tindakan Kelas (PTK) dengan judul
Vol. 4. No. 4 November 2020

p-ISSN: 2598-9944 e- ISSN: 2656-6753
"Upaya Meningkatkan Aktivitas Dan Hasil Belajar Bahasa Inggris Peserta didik Kelas VII4 Semester Satu Tahun Pelajaran 2019/2020 dengan Menerapkan Model Lightening The Learning Climate (Menghidupkan suasana belajar) di SMP Negeri 4 Mataram."

\section{Rumusan Maasalah}

"Bagaimana penerapan model

"Lightening The Learning Climate (Menghidupkan suasana belajar)" pada mata pelajaran Bahasa Inggris peserta didik kelas VII4 semesster satu tahun pelajaran 2019/2020 di SMP Negeri 4 Mataram?"

\subsection{Tujuan Penelitian}

Adapun tujuan yang ingin dicapai dalam pelaksanaan Penilitian Tindakan Kelas(PTK) ini adalah "untuk mengetahui efektifitas penerapan pendekatan Lightening The Learning Climate (Menghidupkan suasana belajar) dalam upaya meningkatkan aktivitas dan hasil belajar Bahasa Inggris peserta didik kelas VII-4 Semester satu Tahun pelajaran 2019/2020 di SMP Negeri 4 Mataram".

\section{Manfaat Penelitian}

- Bermanfaat bagi guru selaku peneliti dalam rangka melaksanakan proses pembelajaran yang kontekstual melalu penerapan model pembelajaran Lightening The Learning Climate (Menghidupkan suasana belajar) di kelas senyatanya serta dalam upaya perwujudan pembelajaran yang aktif, inovatif, kreatif, efektif, dan menyenangkan (PAIKEM) sehingga aktivitas dan hasil belajar peserta didik dapat ditingkatkan.

- Bagi peserta didik sangat bermanfaat dalam upaya peningkatan aktivitas dan hasil belajar yang berdampak meningkatnya prestasi peserta didik dalam pembelajaran Bahasa Inggris.

\section{KAJIAN PUSTAKA}


Jurnal Ilmu Sosial dan Pendidikan

http://ejournal.mandalanursa.org/index.php/JISIP/index

Terakreditasi Peringkat 5 (No. SK: 85/M/KPT/2020)

\section{Kerangka teoritis}

\section{Aktivitas Belajar}

Belajar sangat dibutuhkan adanya aktivitas, dikarenakan tanpa adanya aktivitas proses belajar tidak mungkin berlangsung dengan baik. Pada proses aktivitas pembelajaran harus melibatkan seluruh aspek peserta didik, baik jasmani maupun rohani sehingga perubahan perilakunya dapat berubah dengan cepat, tepat, mudah dan benar, baik berkaitan dengan aspek kognitif afektif maupun psikomotor (Nanang Hanafiah, 2010:23).

Aktivitas belajar adalah aktivitas yang bersifat fisik maupun mental. Dalam proses belajar kedua aktivitas itu harus saling berkaitan. Lebih lanjut lagi piaget menerangkan dalam buku Sardiman bahwa jika seorang anak berfikir tanpa berbuat sesuatu, berarti anak itu tidak berfikir (Sardiman, 2011:100). Nanang Hanafiah dan Cucu Suhana (2010:24) menjelaskan bahwa aktivitas belajar dapat memberikan nilai tambah (added value) bagi peserta didik, berupa hal-hal berikut ini:

1. Peserta didik memiliki kesadaran (awareness) untuk belajar sebagai wujud adanya aktivitas internal untuk belajar sejati.

2. Peserta didik mencari pengalaman dan langsung mengalami sendiri, yang dapat memberikan dampak terhadap pembentukan pribadi yang integral.

3. Peserta didik belajar dengan menurut minat dan kemampuannya.

4. Menumbuh kembangkan sikap disiplin dan suasana belajar yang demokratis di kalangan peserta didik.

5. Pembelajaran dilaksanakan secara konkret sehingga dapat menumbuh kembangkan pemahaman dan berfikir kritis serta menghindarkan terjadinya verbalisme.

6. Menumbuh kembangkan sikap kooperatif dikalangan peserta didik sehingga sekolah menjadi hidup, sejalan dan serasi dengan kehidupan di masyarakat di sekitarnya.

Dalam penelitian ini yang dimaksud dengan aktivitas belajar adalah kegiatan peserta didik mengingat, memecahkan masalah, menganalisis faktor-faktor, melihat hubunganhubungan, dan membuat keputusan terhadap masalah yang diberikan oleh guru mata pelajaran Bahasa Inggris kelas VII-4 di SMP Negeri 4 Mataram.

\section{Hasil belajar}

Mukhtar (2003:54) mengatakan bahwa pengertian hasil belajar tidak dapat dipisahkan dan apa yang terjadi dalam aktivitas pembelajaran baik di kelas maupun diluar kelas. Apa yang dialami oleh peserta didik dalam proses pengembangan kemampuannya merupakan apa yang diperoleh dalam belajar dan pengalaman tersebut pada akhirnya dipengaruhi oleh beberapa faktor diantaranya keadaan kognitif, afektif dan psikomotornya pada waktu belajar. Kualitas pengajaran yang diterimanya dan cara pengelolaan proses interaksi yang dilakukan oleh guru.

Masalah evaluasi hasil belajar meliputi alat ukur yang digunakan, cara menggunakan, cara penilaian dan evaluasinya (Harus Rasid dan Mansur, 2008:9). Evaluasi hasil belajar yang berhubungan dengan tugas guru rutin dilakukan evaluasi hasil, yang juga dijadikan umpan balik, evaluasi hasil bertujuan menilai apakah hasil belajar dicapai sesuai dengan tujuan (Lukmanul Hakim, 2008:165). Pakar pendidikan lain mendefinisikan bahwa yang dimaksud hasil belajar adalah perubahan perilaku secara keseluruhan bukan salah satu aspek potensi kemanusiaan saja (Supriyono, 2009:19). Berbeda dengan pendapatnya Bloom (Dalam Sumiati danAska, 2008). Hasil belajar mencakup kemampuan kognitif, afektif, dan psikomotorik. Jadi pendapat ini mengisyaratkan bahwa haasil belajar peserta didik harus diukur dengan tes tertulis, tes sikap, dan kemampuan skil secara nyata selama proses pembelajaran di kelas senyatanya.

Dalam penelitian ini yang dimaksud dengan hasil belajar adalah tes ulangan harian yang dilaksanakan secara tertulis pada akhir pembelajaran.

\section{Lightening The Learning Climate (Menghidupkan suasana belajar)}


Suatu kelas dapat dengan cepat menemukan suasana belajar yang rileks, informal dan tidak menakutkan dengan meminta peserta didik untuk membut humor-humor kreatif yang berhubungan dengan materi kuliah. Strategi ini sangatlah informal, akan tetapi pada waktu yang sama dapat mengajak peserta didik untuk berpikir.

\section{Langkah-langkah :}

1. Jelaskan kepada peserta didik bahwa anda akan memulai pelajaran dengan aktivitas pembuka yang menyenangkan sebelum masuk ke materi yang lebih serius

2. Bagi peserta didik ke dalam kelompokkelompk kecil. Beri kelompok-kelompok kecil itu satu tugas untuk membuat kegembiraan atau kelucuan dari topik, konsep, atau isu dari materi yang anda ajarkan, sebagai contoh dapat dimisalkan halhal sebagai berikut :

- Ilmu pemerintahan; gambarkan satu sistem pemerintahan yang menurut anda paling tidak efektif.

- Matematika; buatlah cara menghitung yang paling tidak efesien

- Ilmu kesehatan; buatlah menu makanan yang sama sekali tidak bergizi

- Grammer; tulislah kalimat yang memuat kesalahan-kesalahan grammer sebanyak mungkin

- Teknik; buatlah suatu jembatan yang nampak akan jatuh

3. Minta kelompok-kelompok tadi untuk mempresentasikan kreasi mereka. Hargai setiap kreasi.

4. Tanyakan "apa yang mereka pelajari tentang materi ita dari latihan ini?"

5. Guru memberi penjelasan atau melanjutkan pelajaran dengan materi lain.

\section{Hipotesis Tindakan.}

Penerapan pendekatan Lightening The Learning Climate (Menghidupkan suasana belajar) dapat meningkatkan aktivitas dan hasil belajar Bahasa Inggris peserta didik kelas VII-4
SMP Negeri 4 Mataram Semester satu Tahun pelajaran 2019/2020.

\section{PROSEDUR PENELITIAN}

Setting Penelitian

Penelitian tindakan kelas (PTK) ini akan dilaksanakan di kelas VII-4 SMP Negeri 4 Mataram Semester satu Tahun pelajaran 2019/2020, dengan jumlah peserta didik sebanyak 33 Orang.

\section{Faktor yang Diteliti}

- Faktor Guru: yaitu dengan mengganti cara guru membuat Rencana Pelaksanaan Pembelajaran (RPP) dan pelaksanaannya dalam pembelajaran di kelas senyatanya dengan menerapkan pendekatan Lightening The Learning Climate (Menghidupkan suasana belajar) dalam upaya meningkatkan aktivitas dan hasil belajar Bahasa Inggris peserta didik Kelas VII-4 SMP Negeri 4 Mataram.

- Faktor Peserta didik: yaitu peningkatan aktivitas belajar peserta didik yang terlihat pada perilaku peserta didik selama diskusi kelompok, dan pada saat tes tertulis pada akhir pembelajaran bagi peserta didik kelas VII-4 Semester satu Tahun pelajaran 2019/2020 di SMP Negeri 4 Mataram.

\section{Rencana Tindakan}

Kegiatan nyata di kelas VII-4 yaitu melaksanakan proses pembelajaran dengan menerapkan pendekatan Lightening The Learning Climate (Menghidupkan suasana belajar) dalam upaya meningkatan aktivitas dan hasil belajar Bahasa Inggris peserta didik kelas VII.1 SMP Negeri 4 Mataram Semester satu Tahun pelajaran 2019/2020. Tindakan nyata yang dilakukan oleh guru selaku peneliti adalah dengan menggunakan siklus. Gambaran siklus dalam penelitian ini adalah sebagai berikut: 


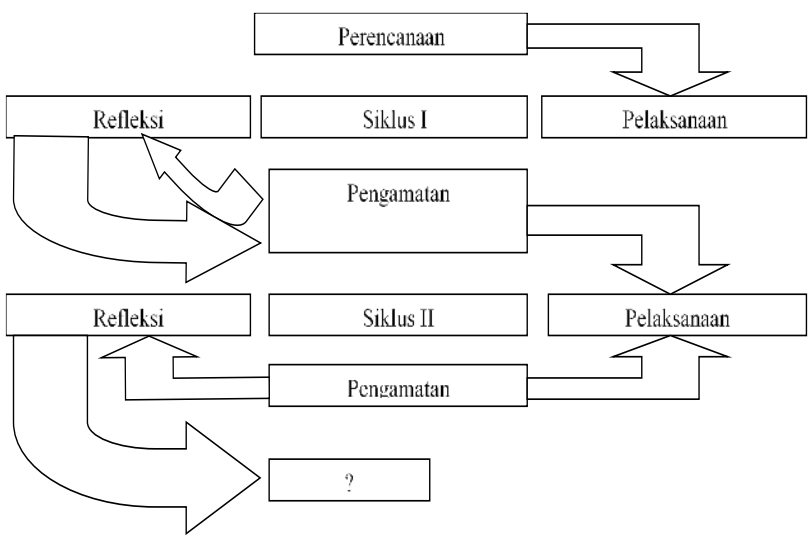

Setiap siklus selama penelitian ini berisi 4 (empat) tahapan yaitu: 1) Perencanaan (Planning), 2) Pelaksanaan (Action), 3) Observasi (Observation), dan 4) Refleksi (Reflection).

\section{Siklus Tindakan}

\section{SIKLUS I}

\section{Tahap Perencanaan (Planning)}

1. Pada tahapan ini guru selaku peneliti melakukan kegiatan-kegiatan sebagai berikut:

2. Menyusun Rencana Pelaksanaan Pembelajaran (RPP) dengan skenario sesuai dengan aturan main model pembelajaran Lightening The Learning Climate (Menghidupkan suasana belajar).

3. Menyiapkan sumber, bahan, dan semua alat yang digunakan dalam penelitian.

4. Menyusun/membuat lembar observasi guru dan lembar observasi peserta didik.

5. Menyusun alat evaluasi.

\section{Tahap Pelaksanaan (Action) \\ Pertemuan ke I}

Pada tahapan ini guru selaku peneliti melaksanakan proses pembelajaran dengan penerapan model pembelajaran Lightening The Learning Climate (Menghidupkan suasana belajar) dengan skenario sebagai berikut :

1. Guru membagi peserta didik menjadi 8 (delapan) kelompok kecil, masing-masing kelompok beranggotakan 4-5 orang peserta didik.
2. Masing-masing kelompok diberikan tugas/soal untuk dipecahkan bersama dalam kelompok,

3. selanjutnya kelompok mendiskusikan tugas yang diberikan dan mengumpulkan secara individu

Pertemuan ke 2

4. Masing-masing kelompok mempresentasikan hasil kerja kelompoknya dihadapan semua peserta didik secara bergiliran.

5. Tes tertulis

\section{Tahap Observasi (Observation)}

- Observasi guru : Dilakukan oleh pengawas mata pelajaran Bahasa Inggris observer sekaligus sebagai pembimbing guru dalam melaksanakan Penelitian Tindakan Kelas (PTK).

- Observasi Peserta didik : Dilakukan oleh guru mata pelajaran sekaligus sebagai peneliti dalam Penelitian Tindakan Kelas (PTK) pada kegiatan diskusi kelompok dan presentasi kelompok.

4). Tahap Refleksi (Reflection)

- Renungan hasil perolehan data

- Pengolahan dan analisa data hasil penelitian

- Mencocokkan hasil analisa data dengan indikator keberhasilan

- Rencana perbaikan dan tindak lanjut

\section{SIKLUS II}

Pada siklus ini semua kegiatan dan tahapan selama penelitian adalah sama, sifatnya mengulang dan memperbaiki terhadap tindakan yang masih memerlukan penyempurnaan dan pembenaran sebagaimana mestinya.

\section{Data dan Cara Pengambilannya. Sumber Data}

Yang menjadi sumber data dalam penelitian tindakan kelas (PTK) ini adalah semua peserta didik kelas VII-4 Semester satu Tahun pelajaran 2019/2020 di SMP Negeri 4 Mataram dan guru Bahasa Inggris selaku peneliti.

\section{Jenis Data}


- Jenis data yang berasal dari guru selaku peneliti

1). Data tentang Rencana Pelaksanaan Pembelajaran (RPP)

2). Data Pelaksanaan Pembelajaran

- Jenis data yang berasal dari peserta didik

1). Data kemajuan aktivitas belajar

2). Data hasil diskusi kelompok

3). Data hasil belajar peserta didik

\section{Cara Pengambilan data}

- Data kegiatan pembelajaran diambil dari RPP yang dibuat oleh guru dan lembar observasi pelaksanaan model pembelajaran Lightening The Learning Climate (Menghidupkan suasana belajar)

- Data kemajuan aktivitas belajar; diambil dari lembar observasi selama kerja kelompok.

- Data kemajuan hasil belajar; diambil dari nilai hasil tes tertulis yang dilaksanakan pada akhir proses pembelajaran

\section{Indikator Keberhasilan dan Teknik analisa data}

Teknik analisa data

Untuk menganalisis data akan dilakukan melalui analisis deskriptif kuantitatif melalui pendataan, analisis dan pembahasan terhadap data yang diperoleh dengan mencocokkan tingkat keoptimalan terhadap capaian indikator keberhasilan yang ada.

\section{Indikator Keberhasilan}

- Guru dinyatakan telah berhasil melaksanakan proses pembelajaran dengan pendekatan Lightening The Learning Climate (Menghidupkan suasana belajar), bila telah mencapai skor rata-rata $\geq 4,00$

- Aktivitas belajar Bahasa Inggris peserta didik kelas VII-4 dinyatakan telah meningkat jika $\geq$ $85 \%$ dari jumlah peserta didik telah memperoleh skor perolehan skor rata-rata $\geq$ 4,0 (kategori aktif) dan hasil belajar dinyatakan telah meningkat jika $\geq 85 \%$ dari jumlah peserta didik memperoleh nilai ratarata $\geq 75,00$ (KKM Peserta didik).

\section{LAPORAN HASIL DAN PEMBAHASAN Laporan Hasil DESKRIPSI SIKLUS I \\ Tahap Perencanaan}

Pada tahapan ini yang telah dilakukan oleh guru selaku peneliti adalah; 1) menyusun RPP dengan skenario pembelajaran Lightening The Learning Climate (Menghidupkan suasana belajar), 2) telah berhasil menyiapkan alat, sumber, bahan yang diperlukan dalam penelitian, 3) berhasil menyusun instrument observasi guru dan instrument observasi peserta didik, dan 4) menyusun alat evaluasi.

\section{Tahap Pelaaksanaan \\ Pertemuan ke I}

Pada tahapan ini guru selaku peneliti melaksanakan proses pembelajaran dengan penerapan model pembelajaran Lightening The Learning Climate (Menghidupkan suasana belajar) dengan skenario sebagai berikut :

1. Guru membagi peserta didik menjadi 8 (delapan) kelompok kecil, masing-masing kelompok beranggotakan 4-5 orang peserta didik.

2. Masing-masing kelompok diberikan tugas/soal untuk dipecahkan bersama dalam kelompok,

3. selanjutnya kelompok mendiskusikan tugas yang diberikan dan mengumpulkan secara individu

\section{Pertemuan ke 2}

4. Masing-masing kelompok mempresentasikan hasil kerja kelompoknya dihadapan semua peserta didik secara bergiliran.

5. Tes tertulis

Tahap Observasi

Observasi guru memperoleh skor rata-rata pertemuan I $(3,00)$ pertemuan II $(3,64)$, Observasi peserta didik memperoleh skor ratarata pertemuan I $(2,94)$ pertemuan II $(3,36)$, dan hasil belajar diambil dari hasil tugas dan tes tertulis yang dilakukan memperoleh nilai ratarata sebesar $(67,27)$ dan $(67,52)$.

\section{Tahap Refleksi}

- Renungan data hasil perolehan data pada siklus I 
- Pengolahan data hasil observasi guru, peserta didik dan tes tertulis.

- Mencocokkan hasil yang ada dengan Indikator keberhasilan.

- Merencanakan perbaikan terhadap jenis tindakan yang menyebabkan belum tuntas Indikator keberhasilan. Oleh karena Indikator keberhasilan belum terbukti maka penelitian dilanjutkan ke siklus II.

\section{DESKRIPSI SIKLUS II}

\section{Tahap Perencanaan}

Pada tahapan ini jenis kegiatan yang dilakukan masih mengacu pada kegiatan siklus I, bedanya hanya terjadi perbaikan seperlunya yaitu: 1) penyusunan RPP dengan mengacu pada pendekatan Lightening The Learning Climate (Menghidupkan suasana belajar) dan penyempurnaan pada bagian skenario pembelajaran, 2) menyiapkan alat, sumber, bahan yang diperlukan dalam proses tindakan dikelas senyatanyan, 3) menyiapkan lembar observasi guru dan lembar observasi peserta didik sebagaimana pada siklus I, 4) menyiapkan alat evaluasi sebagaimana yang telah dibuat pada siklus I.

\section{Tahap Pelaksanaan}

Secara umum tahapan pelaksanaan proses pembelajaran pada siklus II ini masih mengacu pada pelaksanaan proses pembelajaran sebelumnya. Pemecahan yang dilakukan pada proses pembelajaran ini adalah: 1) pelaksanaan proses diskusi kelompok kecil lebih dioptimalkan, 2) pelaksanaan pembimbingan kelompok sekaligus observasi peserta didik lebih di efektifkan. Utamanya pengamatan peserta didik yang aktif, yang kurang aktif, peserta didik yang tidak aktif, dengan harapan proses analisa data lebih signifikan, 3) laporan hasil kerja kelompok yang dibuat secara individu lebih difokuskan, dan 4) pelaksanaan tes tertulis sebagai dampak dari peningkatan aktivitas belajar peserta didik lebih diperketat.

\section{Tahap Observasi}

Observasi guru memperoleh skor rata-rata pertemuan I $(4,00)$ pertemuan II $(4,36)$, Observasi peserta didik memperoleh skor rata- rata pertemuan I $(4,06)$ pertemuan II $(4,61)$, dan hasil belajar diambil dari hasil tugas dan tes tertulis yang dilakukan memperoleh nilai ratarata sebesar $(77,88)$ dan $(83,15)$

\section{Tahap Refleksi}

- Renungan atas perolehan data hasil observasi guru, observasi peserta didik, dan hasil tes tertulis sebagai dampak dari peningkatan aktivitas belajar peserta didik di kelas senyatanya.

- Pengolahan data hasil observasi guru, observasi peserta didik dan tes tertulis

- Mencocokkan perolehan data hasil tindakan dengan Indikator keberhasilan yang telah ditetapkan.

- Guru memberikan hadiah/reward kepada semua peserta didik kelas VII-4 atas keberhasilannya dalam upaya meningkatkan aktivitas belajar yang berdampak terhadap perolehan hasil belajar sesuai dengan KKM yang telah ditetapkan.

\section{PEMBAHASAN \\ SIKLUS I \\ Tahap Perencanaan}

Peneliti telah berhasil menyusun RPP dengan skenario penerapan model Lightening The Learning Climate (Menghidupkan suasana belajar). Peneliti juga telah berhasil menyiapkan alat, sumber, bahan yang diperlukan dalam proses pembelajaran, menyusun instrument observasi guru maupun instrument observasi peserta didik. Kendala yang dihadapi dalam penyusunan alat dan bahan yang diperlukan selama pendampingan adalah yaitu peneliti masih belum menguasai tata cara penyusunan instrument, yang berdampak keterlambatan dalam pelaksanaannya, solusinya peneliti minta petunjuk kepadaa pengawas pembimbing untuk memberikan pembinaan tata cara penyusunan instrument observasi guru maupun penyusunan instrument peserta didik. Setelah diadakan pembimbingan guru matemaatika selaku peneliti berhaasil menyusun lembar observasi guru maupun observasi peserta didik dalam upaya peningkatan aktifitas belajarnya. 
Jurnal Ilmu Sosial dan Pendidikan

http://ejournal.mandalanursa.org/index.php/JISIP/index

Terakreditasi Peringkat 5 (No. SK: 85/M/KPT/2020)

\section{Tahap Pelaksanaan}

Pada tahapan ini guru selaku peneliti melaksanakan proses pembelajaran dengan penerapan model pembelajaran Lightening The Learning Climate (Menghidupkan suasana belajar) dengan skenario sebagai berikut :

1. Guru membagi peserta didik menjadi 8 (delapan) kelompok kecil, masing-masing kelompok beranggotakan 4-5 orang peserta didik.

2. Masing-masing kelompok diberikan tugas/soal untuk dipecahkan bersama dalam kelompok,

3. selanjutnya kelompok mendiskusikan tugas yang diberikan dan mengumpulkan secara individu

4. Masing-masing kelompok mempresentasikan hasil kerja kelompoknya dihadapan semua peserta didik secara bergiliran.

5. Tes tertulis

\section{Tahap Observasi}

Observasi Guru pertemuan I dan II memperoleh skor rata-rata 3,00 dan 3,64. Hasil observasi peserta didik dalam upaya peningkatan aktivitas belajar Bahasa Inggris peserta didik kelas VII-4 Semester satu Tahun pelajaran 2019/2020 di SMP Negeri 4 Mataram pada pertemuan I dan II diperoleh skor rata-rata $(2,94)$ dan $(3,36)$. Perolehan nilai rata-rata tugas individu dan tes tertulis yang dilakukan pada akgir pertemuan adalah massing-masing sebesar $(67,27)$ dan $(67,52)$.

\section{Tahap Refleksi}

Hasil analisa data perolehan aktivitas belajar pada siklus I pertemuan II ini $(3,36)$ sedangkan yang diminta dalam Indikator keberhasilan $(\geq 4,0)$, ini artinya belum berhasil. Karena Indikator keberhasilan belum tercapai, penelitian tindakan kelas (PTK) dilanjutkan ke siklus II dengan harapan optimalisasi penerapan strategi pembelajaran dengan pendekatan Lightening The Learning Climate (Menghidupkan suasana belajar) dapat meningkatkan aktivitas belajar Bahasa Inggris peserta didik kelas VII-4 Semester satu Tahun pelajaran 2019/2020 di SMP Negeri 4 Mataram.
Vol. 4. No. 4 November 2020

p-ISSN: 2598-9944 e- ISSN: 2656-6753

\section{SIKLUS II \\ Tahap Perencanaan}

Peneliti menyusun Rencana Pelaksanaan Pembelajaran (RPP) dengan memperhatikan kesalahan-kesalahan pada siklus I. peneliti lebih memfokuskan tentang Rencana strategi jitu sehingga proses pembelajaran dengan pendekatan Lightening The Learning Climate (Menghidupkan suasana belajar) dapat terelaisasi dengan baik, karenanya dalam penyusunan skenario benar-benar dirinci dari tiap aspek pada proses pembelajaran dengan model Lightening The Learning Climate (Menghidupkan suasana belajar).

Sebelum proses pembelajaran dilaksanakan, peneliti menyiapkan semua alat, bahan, dan segala sesuatunya sehingga dalam pelaksanaan proses pembelajaran berjalan sesuai dengan skenario yang telah direncanakan. Agar proses pembelajaran dapat teratasi maka peneliti juga menyiapkan lembar observasi guru dan lembar observasi peserta didik sebagai tolak ukur ketercapaian peningkatan aktivitas belajar Bahasa Inggris peserta didik kelas VII-4 SMP Negeri 4 Mataram.

\section{Tahap Pelaksanaan}

Pada tahap pelaksanaan di siklus II ini pada dasarnya masih mengacu pada pelaksanaan siklus I, yaitu penerapan pendekatan Lightening The Learning Climate (Menghidupkan suasana belajar). Bedanya pada siklus ini lebih dioptimalkan.

\section{Tahap Observasi}

Pada siklus II ini hasil observasi pada pertemuan I dan II memperoleh skor rata-rata $(4,00)$ dan $(4,36)$. Upaya meningkatkan aktivitas belajar Bahasa Inggris peserta didik kelas VII-4 Semester satu Tahun pelajaran 2019/2020 di SMP Negeri 4 Mataram pada pertemuan I dan II diperoleh skor rata-rata $(4,06)$ dan $(4,61)$. Dampak nyata dari meningkatnya aktivitas belajar adalah hasil belajar juga meningkat, dari data hasil perolehan nilai rata-rata tugas dan tes tertulis adalah $(77,88)$ dan $(83,15)$ sementara pada siklus sebelumnya hanya $(67,27)$ dan 
Jurnal Ilmu Sosial dan Pendidikan http://ejournal.mandalanursa.org/index.php/JISIP/index

Terakreditasi Peringkat 5 (No. SK: 85/M/KPT/2020)

$(67,52)$ berarti mengalami peningkaatan yang signifikan.

\section{Tahap Refleksi}

Hasil analisa data peningkatan aktivitas belajar peserta didik pada siklus II pertemuan II adalah $(4,61)$ sedangkan Indikator keberhasilan $(\geq 4,0)$. Ini artinya pada siklus II hasilnya telah melampaui Indikator keberhasilan.

Karena Indikator keberhasilan telah terbukti, maka tidak perlu ada upaya perbaikan dan penyempurnaan. Pendekatan Lightening The Learning Climate (Menghidupkan suasana belajar) telah mampu meningkatkan aktivitas belajar peserta didik yang ditandai dengan tercapainya Indikator keberhasilan dan terjadinya peningkatan hasil belajar peserta didik. "Penelitian Tindakan Kelas (PTK) dihentikan pada siklus II dengan hasil memuaskan."

\section{SIMPULAN DAN SARAN}

\begin{tabular}{|c|l|c|c|c|c|c|l|}
\hline \multirow{2}{*}{ No } & \multirow{2}{*}{ Jenis Kegiatan } & \multirow{2}{*}{$\begin{array}{c}\text { Indikator } \\
\text { Keberhasilan }\end{array}$} & \multicolumn{2}{|c|}{ Siklus I } & \multicolumn{2}{|c|}{ Siklus II } & \multirow{2}{*}{ Ket } \\
\cline { 4 - 7 } & & & I & II & I & II & \multirow{2}{*}{ 1. } \\
\cline { 1 - 4 } & Hasil Observaasi Guru & $\geq 4,00$ & 3,00 & 3,64 & 4,00 & 4,36 & \multirow{2}{*}{ Tuntas } \\
\hline 2. & Observasi Peserta didik & $\geq 4,00$ & 2,94 & 3,36 & 4,06 & 4,61 & \multirow{2}{*}{ Tuntas } \\
\hline 3. & Hasil Tugas Individual & $\geq 75,00$ & 67,27 & - & 77,88 & - & \multirow{2}{*}{ Tuntas } \\
\hline 4. & Hasil Tes tertulis & $\geq 75,00$ & - & 67,52 & - & 83,15 & \multirow{2}{*}{ Tuntas } \\
\hline
\end{tabular}

Penerapan model Lightening The Learning Climate (Menghidupkan suasana belajar) sangat efektif upaya untuk meningkatkan aktivitas belajar Bahasa Inggris peserta didik kelas VII-4 Semester satu Tahun pelajaran 2019/2020 di SMP Negeri 4 Mataram. Fakta telah menunjukkan perolehan rata-rata skor aktivitas belajar peserta didik pada siklus I pertemuan II $(3,36)$, sedangkan pada siklus II pertemuan II $(4,61)$ sudah melampaui Indikator keberhasilan yang ditetapkan. Hasil belajar peserta didik pada siklus I memperoleh nilai rata-rata $(67,27)$ dan $(67,52)$ sementara pada siklus II meningkat menjadi $(77,88)$ dan $(83,15)$, ini sudah melampaui indikator yang direncanakan. Penelitian dinyatakan "BERHASIL" dan dihentikan pada siklus II.

Disarankan kepada guru sejawat untuk melaksanakan Penelitian Tindakan Kelas (PTK) dalam upaya untuk meningkatkan aktivitas dan atau hasil belajar peserta didik sesuai dengan mata pelajaran masing-masing.

Disarankan kepada para semua peserta didik kelas VII-4 SMP Negeri 4 Mataram untuk membiasakan belajar dengan pendekatan yang kontekstual utamanya strategi yang mampu membangkitkan aktivitas belajar peserta didik yang dampaknya hasil belajar dapat ditingkatkan seperti yang diharapkan.

\section{DAFTAR PUSTAKA}

Anonim, 2019, dalam https://ekokhoerul.wordpress.com/201 2/06/27/konsep-aktivitas-belajarsiswa/, diambil tanggal 8 Juli 2019, pukul 20.45 Wita.

Arikunto, s. 2009, Penelitian Tindakan Kelas, Jakarta : Bumi Aksara.

Harun Rasyid dan Mansur, 2008, Penilaian Hasil Belajar, Bandung : CV Wacana Prima.

Lukmanul A, 2008, Perencanaan Pembelajaran, Bandung : CV Wacana Prima.

Mukhtar, 2003, Prosedur Penilaian, Jakarta : Rineka Cipta.

Nurhadi, 2003, Yasin ,B dan Sendule.A, 2003, Kontekstual dan Penerapannya dalam $K B K$, Malang : Unitipetas Negeri Malang.

Robert E Slavin, 2010, Cooperative Learning Teori, riset dan Praktik, Bandung : Nusa Media.

Sardiman, 2007, Indikator Dan Aktivitas Belajar Mengajar, Jakarta : Raja Grafindo Perkasa.

Supriono, 2009, Cooperative Learning Teori dan Aplikasi PAIKEM, Yogyakarta : Pustaka Pelajar.

\section{Saran-Saran}

